\title{
GEOGRAPHY AND THE MARITIME POTENTIAL OF CHINA AND IRAN
}

\section{Sören Scholvin ${ }^{1}$ and Alexandr Burilkov ${ }^{2}$}

\section{Introduction}

In recent years, developments in Chinese and Iranian foreign policy have been a constant in discussions in the West, particularly in the United States. It is a haphazard process but the Chinese continue to modernize and expand their forces and strategic reach. In the meantime, Iranian political and military leaders are fond of reminding the world of their thousands of missiles that are supposedly but a push of a button away. Outlandish projects aside, when it comes to strictly maritime matters it becomes possible to see that each state has a certain maritime potential, meaning the ability to leverage the near and far seas so as to achieve its objectives at some point in the near future. We seek to show how this potential is influenced by geography.

In 1942, U.S. geostrategist Nicholas Spykman famously wrote that "ministers come and go, even dictators die, but mountain ranges stand unperturbed" (Spykman 1942, 41). A central tenet of classical geopolitics, this maxim shows the timeless role of geography in the turbulent course of human history, which, as posited by British geographer Halford Mackinder, is guided if not outright governed by geographical features (Mackinder 1890, 78). Contrary to popular conceptions of geopolitics as the ruthless pursuit of power, those scholars of the late $19^{\text {th }}$ and early $20^{\text {th }}$ century who stand for the classical geopolitical perspective sought to explain socio-political phenomena through location and physical features in geographical space. This style of analysis has 
become rare with the notable exception of Robert Kaplan's recent contributions on the rise of China and the geopolitics of the Indian Ocean (Kaplan 2009; $2010 \mathrm{a} ; 2010 \mathrm{~b})$. A common misconception is that classical geopolitics is geodeterminist, yet neither we nor the scholars to whom we refer claim that geography mechanistically dictates human action. Rather, we argue that it sets the frame within which human action occurs (Mackinder 1895), action that is presumably bounded by the constraints and opportunities provided by geographic factors. Hence, courses of action that reflect geography in procurement and operational practice are the ones that will be successful in creating effective tools for the completion of objectives. They prevail in the long run and knowing geography therefore helps us to evaluate the maritime potential of challengers to U.S. naval supremacy such as China and Iran.

\section{Shaping Maritime Geopolitics}

To assess the impact of geography on maritime potential, this general category must be divided into several distinct elements. For our purposes, Alfred Thayer Mahan's work is an excellent reference point; following his analyses (Mahan 1890, 29-49), we consider the location and physical geography of a state as well as structural features of its economy. The "national character" and the "character of its government", which Mahan included in his analysis, will not be addressed by us.

First, location matters. Taking up a key idea advanced by Mahan, Spykman reasoned that "it is the geographic location of a country and its relations to centers of military power that define its problem[s] of security" (Spykman 1942, 447). The most advantageous is an island because this only leaves the threat of amphibious invasions and allows states to predominantly concentrate their efforts on the fleet, unlike the typical continental state, which does not only require a fleet and an army but also a separate fleet per sea it borders. This challenge is exacerbated by diffusion of power stemming from a large territory or distant territorial outposts. Sea lines of communication (SLOC), identified as prime targets by Julian Corbett (1911, 94-95), stretch thin and even unsustainable if state capabilities are not sufficient to protect them. Seeing the open seas as "highways", like Mahan (1890, 25-28) did, means that every state should build naval bases along the SLOC on which it is dependent. If a state faces a multidirectional or omnidirectional cohort of maritime rivals, 


\section{Sören Scholvin and Alexandr Burilkov}

this also forces division of naval strength; temporary and localized as it already is (Corbett 1911, 93), command of the sea will become even more difficult.

Moreover, proximity to rivals has a profound effect on naval force structure; large, sophisticated platforms intended for a blue-water navy will take a backseat to a green-water structure composed of aircraft and platforms optimized for amphibious warfare and air defense. As distances increase, the ability of a navy to bring power sufficient to punch through enemy defenses gradually decreases unless one is able to deploy carrier groups that are extensively supported by other naval, air and space assets. Only a tiny minority of states has the infrastructure and experience needed to do so. The stopping power of water, as John Mearsheimer (2001, 44, 77, 114-128) calls it, has been the bane of many continental powers through history and will continue to be a major obstacle to the ambitions of many more, even in the hyper-technological $21^{\text {st }}$ century. After all, there is only so much that ground-based troops and aircraft can do without becoming a projectile to be fired by the navy.

Second, when defined as the terrain and length of the coastline, coastal topography determines the likelihood of a successful amphibious invasion as well as the opportunities for the defenders to setup fixed and mobile positions and to construct hardened facilities and ports able to support maritime operations. The longer the coast, the more difficult it becomes to engage in rapid, strategically decisive operations. Difficult terrain, from broken hills and cliffs to mud flats and deltas, can greatly hamper any invaders and force them into geographically determined chokepoints. If a state's primary orientation is defensive or relies heavily on a brown water approach, strategic depth will become a prime objective, whether it is achieved by dispersion across wide distances, camouflage in urban terrain, multiple hardened facilities or a combination thereof. An asymmetric war of attrition that seeks to blunt the impact of a naval invasion will be more likely if there are few strategic targets close to shore, as it is easier to use defense in depth and fortified urban areas to bleed the invaders dry and try for a political victory.

Third, trade, i.e. the acquisition of key supplies for a state's economy and defense sector, is bound to geography. Maritime commerce depends on SLOCs, which can be targeted for great effect. 90 percent by volume and 80 percent by value of global trade relies on maritime transportation, including all 
strategic hydrocarbon and rare earth resources. For states without domestic production of such commodities, strategic reserves, especially oil, become necessary; they are costly to maintain but without them, systematic disruption of oil imports can grind to a halt even the mightiest of economies. Many multinational businesses make use of just-in-time logistics to reduce overhead, but this makes them highly sensitive to instability at any given point in the supply chains, whether it stems from unpredictable events like natural and environmental disasters or completely intentional and hostile disruption. Linking the geostrategic relevance of SLOCs to locational factors, proximity to rival or even neutral trade lanes makes it easier to disrupt them; and commerce raiding is a naturally dispersed approach that presents a real and multilayered challenge to the defender. The brazen piracy in the Gulf of Aden and the Straits of Malacca shows that it is not even necessary to have the full array of a state's resources to be able to do so. In any case, global trade in general is a strong motivator for a large navy, both to protect one's own trade and to disrupt the trade of adversaries in the event of conflict. Therefore, we refer to transport and resources as indicators for the trade orientation of a state, which can be either continental or maritime (Spykman 1938, 229-236), in order to assess its dependence on maritime transport and resulting vulnerability to according disruptions.

Lastly, not only maritime defense, also offense depends on geography: Following Spykman (1942, 90-91; 1944, 23, 28-33), topography is essential for maritime offense because of its impact on transport and resources. If one seeks to go on the offensive, to deploy multiple large vessels and shoot for command of the sea, then it is more advantageous to have a long, populated coastline with several deepwater ports and extensive transport and infrastructure links to the heartland and its industrial base as well as the global trade network and its suppliers of resources and technology. Topography moreover provides directions of comparatively easy, economically and strategically beneficial expansion. Expansion into certain areas (e.g. coasts with natural harbors), some forms of expansion (e.g. circumferential control of large seas), or even the geography-based course of SLOCs (e.g. from one small island to another) are simply speaking rational (Spykman and Rollins 1939). 


\section{China: A Maritime Power Constrained by Unfavorable Geography}

The sea and the numerous SLOCs that crisscross are vital to China's economy. Exports of manufactured goods and imports of mineral resources remain preeminent, totaling USD 1.6 trillion in 2010, the largest for any single country. Nine of the world's 20 busiest ports by tonnage are in China, and this massive engine of export, based as it is on just-in-time logistics, is sensitive to disruption. The energy consumption of the People's Republic is expected to increase drastically. Coal-fired plants are the main source of energy consumption and indigenous sources can fill the rising demand. This is not true for hydrocarbons; China already imports 1.6 billion barrels of oil and 7.5 billion cubic meters of natural gas per year. Development of shale oil reserves in Xinjiang remains slow and, despite a considerable potential, unable to fill energy needs (Yunlai, Hua and Kai 2011), so China will continue to turn to foreign suppliers. Natural gas needs can be filled to an extent by Russia and Central Asian states, and this conveniently uses established land pipelines in friendly states of the Shanghai Cooperation Organization (SCO), thus bypassing the need for seaborne transport. Rising demand may, however, strain the infrastructure and place even greater focus on Indonesia, China's main supplier of natural gas by sea. Oil is another question. Imports from the Persian Gulf alone hovering around 50 percent, while the rest is filled up by African and, increasingly, Latin American sources. In any case, most oil imports to China must transit either the Straits of Malacca or Lombok, where they are perceived as exposed to Indonesia and Singapore, two states that may not be entirely friendly to Chinese goals, as well as hostile criminal, pirate, and terrorist groups active in these waters.

Given these threats to China's economic prosperity, it is not surprising that rising China looks to the sea. It is not the first time in Chinese history. Whenever a Chinese dynasty was not threatened by nomads at its borders or internal rebellions, it sought to expand its reach; the most spectacular example is Zheng He's exploration fleets in the $15^{\text {th }}$ century, consisting of armed merchant junks many times the tonnage of Columbus' caravels. They carried Chinese power as far as the Indian Ocean. But being able to break out into maritime power in this fashion has always been a significant challenge given the geography of the Western Pacific, dominated above all by islands like Guam, 
Japan and Taiwan. Because of its location at the coast of the Eurasian land mass, China also had to split its attention between a long land border and the sea. The Japanese, benefiting from a geostrategic position very similar to the one of England, have long contested Chinese supremacy through maritime power, most spectacularly during the Shogunate's invasions of Korea at the turn of the $16^{\text {th }}$ century. During a long century of "humiliation" from the $1830 \mathrm{~s}$ to the 1940s, a naval built-up was unthinkable for the Qing Dynasty and later the Kuomintang, both unable to resist European and Japanese invasions. After the Communist revolution, the lack of maritime assets left the People's Republic unable to reclaim Taiwan from the Nationalists, unlike the other "wayward provinces", forcing an uneasy stalemate that continues to this day.

Nonetheless, China certainly holds many geographical advantages in developing strong naval capabilities. They result from the fact that the economic cores of China are located along its coast line. These cores are marked by a booming shipbuilding sector, large populations, well-developed ports, and an extensive scientific and technical infrastructure that is able to indigenously develop weapons systems to a great extent. The People's Liberation Army (PLA) can deploy capabilities across the full spectrum of military theaters: land, sea, air, space and cyberspace (Office of the Secretary of Defence 2011, 2740). But for all its power, we argue that the geographic constraints we already touched upon severely limit China's strategic choices about the use of naval forces or, in other words, its potential as a maritime power.

First, the need to protect its economic growth drives China to explore the establishment of a naval presence in the Indian Ocean and beyond that is more permanent than their current counter-piracy mission in the Gulf of Aden. At the same time, the Pacific Ocean is China's prime maritime theater, especially since the decision of the Obama administration to boost its navy there. The problem that arises from this for China follows the classical line of thought on the division of naval forces by theater as weakening the overall concentration of power (Mahan 1890, 29). The U.S. Navy may be able to manage this situation and still project considerable power across all theaters, but for China, whose military and scientific structures remain significantly constrained despite recent growth, it is a significant drawback, forcing tough choices on where to prioritize warship stationing and deployment. This disadvantage is enforced by the fact that China does not possess a coastline on 


\section{Sören Scholvin and Alexandr Burilkov}

the Indian Ocean, depriving its fleet of safe harbors. Even as China-sponsored deepwater ports like Gwadar in Pakistan and Dawei in Myanmar are established, China is likely to limit the size of forces deployed in the Indian Ocean (Kostecka 2011, 60-61). Building a Chinese naval base or at least a resupply station on the Seychelles, as offered by the island state discussed during a visit of China's Defense Minister in 2011 (Simpson 2011), remains an uncertain yet geostrategically important vision. Given these geographical disadvantages, the People's Republic can, at least in the Indian Ocean, be balanced by India. It is in no position to challenge the United States there. Ultimately, this may present strong incentives for China to be more than a pure competitor and instead become a valued partner in Military Operations Other Than War (MOOTW) operations in the South Asia region.

Second, in the Chinese littoral, Taiwan and its navy is the main immediate obstacle to the People's Liberation Army Navy (PLAN) ambitions, especially when it comes to projecting power further away from the coast through major surface combatants and long-range aircraft. Taiwan may be immobile, but mountainous as it is, it represents a perfect example of the "unsinkable aircraft carrier". Thus, Taiwan encapsulates the dichotomy central in Chinese naval thinking. On one hand, the PLAN has pursued the so called "Offshore Active Defense" doctrine since 1985, perceiving that it stands to gain much by being able to project a defensive perimeter up to the first island chain, stretching from Okinawa to the Spratlys, or even more ambitiously to a second island chain that encompasses even Guam and the Philippines (Cole 2003, 130133). ${ }^{3}$ This would entail a strategy of sea control via major surface combatants and advanced submarines. On the other hand, as long as an island as large and as fortified as Taiwan stays outside Beijing's control while pursuing close security ties with the United States, such a strategy is simply unfeasible and this manifests in China's concerted efforts at developing advanced long-range and anti-satellite missiles and directed energy weapons. The objective here is to deny access to opposing forces (Anti-Access/Area Denial or A2AD), especially

3 The website GlobalSecurity.org provides a concise description of the "Offshore Active Defense" doctrine: http://www.globalsecurity.org/military/world/china/plan-doctrine-offshore.htm. 
the U.S. Navy, to waters several hundred nautical miles from the Chinese coast. In effect, Taiwan turns the Western Pacific into a zero-sum game, giving very significant forward basing advantages to whoever it aligns with. China cannot hope to break out of the littoral and project power further without asserting control over Taiwan first. Missiles, submarines and to a certain extent destroyers form the core of China's hybrid strategy in the Pacific Ocean, layering a defensive aspect in depth with a more offensive aspect aimed at highvalue targets like carriers and bases ( $O^{\prime}$ Rourke 2012, 8-40). If Taiwan were to be integrated in some capacity into a distributed defense network as envisioned by the proposed Air Sea Battle strategy, it would become even more imperative for China to neutralize it, even as it would become more difficult for them to do so successfully. The same logic explains, regardless of ultra-nationalist rhetoric, the intensity of the recent confrontation over the Diaoyu/Senkaku Islands.

\section{Iran: Asymmetric Warfare as a Reflection of Geography}

Strategically, looking to the sea has been an unaffordable luxury for most of Persian history, with successive waves of foreign invaders making defense of the vast land borders far more crucial. Piracy, once rampant in the Persian Gulf, was neutralized by Portuguese and then British colonial forces; and with no Persian fleet to assert control, the British were able to gain control over vast wealth through the Anglo-Persian Oil Company (APOC), one of the forerunners of British Petrol (BP). It was not until the 1960s and 1970s that Iran acquired significant maritime assets. Geographic considerations dictated such force composition. The Shah regime relied on oil exports for its wealth and these SLOCs had to be protected from interference. Furthermore, persistent disputes over control of the Shatt al-Arab waterway and the desire of Iraq under the Baath Party to rise to regional hegemony led Iran and Iraq on a collision course. To gain sea control in the Persian Gulf, the Shah used his favored antiCommunist status with the West, especially his privileged role as regional proxy of the United States, to extensively arm the Iranian Navy with modern warships, including British Vosper-class frigates, which remain active to this day.

The 1979 revolution and subsequent Iran-Iraq War did little to change the geographic calculus, as the main threat remained Iraq, with the conservative Arab oil-exporting Gulf States, which supported Iraq heavily for 


\section{Sören Scholvin and Alexandr Burilkov}

the First Gulf War, added. The Iranian Navy asserted maritime supremacy from the onset and maintained the Tanker War, aiming to damage Iraq's oil exports. It was not until 1988, when the United States launched Operation Praying Mantis in retaliation for Iranian mining of the Gulf, that the geographic aspect of Iranian strategy changed. The change was significant: the Iranians faced a powerful new adversary and could no longer hope to assert sea control with the means of symmetric warfare. With the fall of the Soviet Union and the dramatic defeat of Iraq in 1991, Iran found itself in a situation unprecedented in its history, given that its main rivals suddenly came from the sea rather than land; the Gulf States were arrayed in the immediate vicinity, while British and U.S. warships lurked beyond the Strait of Hormuz. This paradigm shift prompted a reconsideration of strategic priorities based on the geographic context of the threat (Office of Naval Intelligence 2009, 7). Ever since then, Iran's maritime potential has been characterized by three geographical aspects:

First, the most defining feature of the Persian Gulf is the narrow chokepoint at the Strait of Hormuz. Its strategic importance cannot be overstated. Only 54 kilometers wide at its narrowest points, its navigable channels see an average of 15.5 million barrels of oil every day, representing one third of seaborne oil traffic and almost one fifth of total world production. At its northern edge sits a constellation of rocky islands and the busy Iranian port of Bandar Abbas. The strait gives its controller enormous leverage over its neighbors and the world economy. To secure its control over the strait, Iran has built a distributed defense network that uses the many small islands to conceal stationary emplacements and small fast-attack and patrol craft (Cordesman and Seitz 2009, 16). Qeshm, the largest of these islands, was once occupied by Portuguese and British colonial forces, operating with impunity in Safavid Persia's littoral. In case of a military confrontation between Iran on the one side and Israel (and the United Stated) on the other side, Iran will most likely attempt to close the Strait of Hormuz. Existing garrisons would certainly be augmented by aircraft, submarines and extensive mine laying operations. The Revolutionary Guards and proxies of Iran such as Hezbollah can be expected to launch terrorist attacks against Israeli and U.S. targets worldwide. In the long term, the closure of the Strait of Hormuz would also be devastating to the 
Iranian economy, but it remains a potent threat. The tyranny of geography is on full display there, and despite the many advances in remote sensing and robotics that aim to blunt such asymmetric warfare, it remains impossible to neutralize every threat, especially when a natural chokepoint allows for the concentration of nimble asymmetric maritime forces. Taking a look at the history of the Persian Gulf reveals how likely such a scenario is: at the end of the First Gulf War, the Iranians attacked tankers in the Persian Gulf and mined parts of it, which eventually led to the internationalization of the conflict.

Second, the narrowness of the Persian Gulf means short reaction times and the myriad small islands and swamps on the Iranian coast gives good concealment to small, fast boats and mobile missile launchers. The forces of the Iranian Navy and the Revolutionary Guards Navy can be expected to take full advantage of this in deploying the kind of asymmetric approach on display at the U.S. Navy's Millennium Challenge 2002 war game. Furthermore, unlike in China, where the littoral is highly developed, Iran's coast is not. Most major cities are further inland; thus, Iran possesses true strategic depth, although the lack of littoral development also stymies the infrastructure and personnel factors identified as crucial to naval power. When making strategic choices, Iran therefore faces many material constraints. From a maritime perspective, maximizing security is achieved by respecting the geographic context and investing in relatively low-cost and plentiful asymmetric warfare systems like anti-ship missiles, backed up by silent diesel-electric submarines. The Iranians have been able to acquire advanced Kilo-class submarines from the Russians as well as advanced missiles from the Chinese despite international pressure (Cordesman and al-Rodhan 2006, 29-30, 33). Even if this fairly comprehensive A2AD approach fails to completely stop enemy attacks or invasion attempts, it has the potential to extract a high cost to the attackers. This means that conventional forces adapted to modern understanding of warfare on the high seas are well-suited to the Western Pacific and ideal for the burgeoning concept of Air Sea Battle but they would not do so well if forced to breach the constricted littoral defenses at the strait. Iran's gamble is to hold out long enough to turn such a hypothetical conflict into a war of attrition, and thus force the kind of unacceptable casualties and material costs that would lead to a political victory. 


\section{Sören Scholvin and Alexandr Burilkov}

Third, the Persian Gulf does not only provide geographical advantages to Iran's maritime potential. Iran may have prioritized A2AD but this means that few resources are left to develop frigates or corvettes, multi-mission vessels able the handle the kind of MOOTW operations that are becoming commonplace for navies across the globe and which, for Iran, would also include counter-piracy in the neighboring Western Indian Ocean. Hence, while India is able send multiple warships, Iran can only intermittently deploy a single, aging Vosper-class frigate and a helicopter (Stratfor 2013). Going against geography by attempting to field major surface combatants and other more conventional assets would not only be prohibitively expensive but would achieve suboptimal results if matched against the maritime power of Iran's chief rivals, regional or otherwise. This highlights the difficulty for Iran of ever being able to break out of the Persian Gulf and range into the Indian Ocean because the chokepoint, which controls the entrance to the Gulf and channels oil tankers, also leaves Iranian naval forces vulnerable and exposed to extensive surveillance. Somehow like China, whose navy has to operate in two oceans, the Iranians need maritime capacities for the shallow Persian Gulf and for the Indian Ocean. In other words, the geographical forces that favor asymmetric warfare in the Persian Gulf make Iran weak beyond the Strait of Hormuz. This division of theaters matters much because the question of breaking out of the Persian Gulf is not merely one of prolonging reach. It also affects Iran's defensive capacities in a confrontation with any major maritime power: by ceding the Western Indian Ocean to others, Iran possesses no means to counter the deployment of nuclear submarines, which can be outfitted with long-range cruise missiles, and long-range aircraft there.

\section{Outlook}

As this paper has shown, geography plays a significant role for the maritime potential of China and Iran. It provides opportunities and constraints and, this way, guides the strategic choices taken by these two emerging powers. However, one should bear in mind that geography interacts with various other factors that influence the maritime potential of states. Even though geography itself is persistent, its specific impact on maritime potential may shift due to non-geographical factors: technology transfers and security agreements shore 
up maritime potential, while strong rivals that engage in sustained containment and accelerated shipbuilding programs erode it. Specifically, technology and its rapid progress play a decisive role, as it allows navies to mitigate constraining geographic factors to a certain degree.

At the same time, one may argue that geography accounts for much more than what we have analyzed in this paper. Some adherents of classical geopolitics went beyond rather modest physiocratic reasoning on geographical advantages and disadvantages. For example, James Fairgrieve (1915, 66) posited that geography reacted on the mind and so caused it to choose courses of action. Using contemporary language, geography induces what Colin Gray calls "strategic orientations". Gray (1988, 43, 45-52, 58; 1991, 313-315; 1996, 257-258) reasons that experiences with geographic factors in the long run cause states to develop unique strategic cultures, meaning that their foreign policy thinking is shaped by their past interaction with geographical constraints and opportunities.

In the cases of China and Iran, we do indeed find strategic orientations that appear worthwhile being investigated further: China's cautious efforts to build blue water naval assets in order to protect its SLOCs, along with projects to establish deepwater ports in Burma, Pakistan and Iran reflect centuries of expansion shaped by the seas and rivers. From the destruction of the Song Dynasty at the hands of the Mongols, to the glory of the Ming Dynasty and Zheng He's exploration fleets, then setbacks at the hands of Wokou pirates and Japanese invaders during the Qing Dynasty, and finally the showdown with Taiwan, Chinese strategic freedom of action was always greatest when they were able to field significant naval power. This experience of strategic rewards of breaking out into the sea appears to shape present-day Chinese strategic orientation. Meanwhile, the inability of the Persians to defend even the islands closest to their shores from successive Portuguese and British invasions, partly motivated by pirate activity in the Persian Gulf, made their eventual loss of freedom of action in the early $20^{\text {th }}$ century all but inevitable. This harsh lesson is one that the current Islamic Republic would not like to see repeated. Such geographically induced, cognitive fundaments of maritime strategies should be a vital component of geostrategic assessment and planning. 


\section{Sören Scholvin and Alexandr Burilkov}

\section{REFERENCES}

Cole, Bernard D. 2003. "The PLA Navy and "Active Defense". In The People's Liberation Army and China in Transition, edited by Stephen J. Flanagan and Michael E. Marti. Washington D.C.: National Defense University Press.

Corbett, Julian S. 1911. Some Principles of Maritime Strategy. London: Longman.

Cordesman, Anthony H.; and Khalid R. al-Rodhan. 2006. The Gulf Military Forces in an Era of Asymmetric War. Washington D.C.: CSIS.

Cordesman, Anthony H.; and Adam C. Seitz. 2009. Threats, Risks and Vulnerabilities: Terrorism and Asymmetric Warfare. Washington D.C.: CSIS.

Fairgrieve, James. 1915. Geography and World Power. London: University of London Press.

Gray, Colin S. 1988. The Geopolitics of Super Power. Lexington: University Press of Kentucky.

. 1991. "Geography and Grand Strategy." Comparative Strategy 10 (4): 311-329.

. 1996. "The Continued Primacy of Geography: A Debate on Geopolitics." Orbis 40 (2): 227-259.

Kaplan, Robert D. 2009. "Center Stage for the Twenty-first Century: Power Plays in the Indian Ocean." Foreign Affairs 88 (2): 16-32. . 2010a. "The Geography of Chinese Power: How Far Can Beijing Reach on Land and at Sea?." Foreign Affairs 89 (3): 22-41.

. 2010b. Monsoon: The Indian Ocean and the Future of American Power. New York: Random House.

Kostecka, Daniel J. 2011. “The Chinese Navy's Emerging Support Network in the Indian Ocean." Naval War College Review 64 (1): 59-78.

Mackinder, Halford J. 1890. "The Physical Basis of Political Geography." Scottish Geographical Magazine 6 (2): 78-84.

. 1895. "Modern Geography: German and English." Geographical Journal 6 (4): 367-379.

Mahan, Alfred T. 1890. The Influence of Sea Power upon History: 1660-1783, London: Sampson Low Marston. 
Mearsheimer, John J. 2001. The Tragedy of Great Power Politics. New York: Norton 2001.

O'Rourke, Ronald. 2012. China Naval Modernization: Implications for U.S. Navy Capabilities. Washington D.C.: CRS Report for Congress.

Office of Naval Intelligence. 2009. Iran's Naval Forces: From Guerilla Warfare to a Modern Naval Strategy. Washington D.C.: Office of Naval Intelligence.

Office of the Secretary of Defense. 2011. Military and Security Developments Involving the People's Republic of China 2011. Washington D.C.: Department of Defense.

Simpson, Peter. 2011. "China Considers Seychelles Military Base Plan." The Telegraph, September 13. 


\title{
Sören Scholvin and Alexandr Burilkov
}

\begin{abstract}
Geographical factors - in particular location, length and terrain of the coastline, and SLOCs - enable us to assess the maritime potential of two key emerging powers: China and Iran. Referring to said geographical factors, we also derive specific features of the Chinese and Iranian naval strategies, and conclude with an outlook on their geographically shaped "strategic cultures". Pursuing this approach to international relations/security studies, we seek to revitalize classical geopolitical thinking.
\end{abstract}

\section{KEYWORDS}

Geopolitics; Naval Strategy; Asymmetric Warfare; China; Iran. 